$\mathrm{PP} \mathrm{B}=$

\title{
Influence of fluorescent Pseudomonas on the growth of Mimosa scabrella seedlings
}

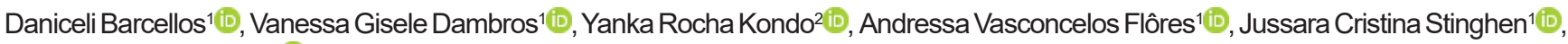 \\ Glória Regina Botelho ${ }^{1 *}(\mathbb{D})$
}

${ }^{1}$ Universidade Federal de Santa Catarina, Rodovia Ulysses Gaboardi, 3000, CEP 89520-000, Curitibanos, SC, Brasil

Universidade Federal do Paraná, Rua dos Funcionários, 1540, Cabral, CEP 80035-050, Curitiba, PR, Brasil

\author{
"Corresponding author: \\ gloria.botelho@ufsc.br \\ Index terms: \\ Legumes \\ Rhizobacteria \\ Growth \\ Termos para indexação: \\ Leguminosas \\ Rizobactérias \\ Crescimento
}

Received in 26/12/2019

Accepted in 09/12/2020

Published in 20/05/2021

\begin{abstract}
Bracantiga (Mimosa scabrella Benth) is a native leguminous specie from the south of Brazil, with great potential for commercial use. It can be used to recover degraded areas due to their fast growth, high adaptability and root nodule formation capacity. One alternative to reduce fertilization costs of seedlings production, are the plant growth promoting rhizobacteria. The fluorescent group of Pseudomonas is common at several plant rhizosphere. The objective of this work was to assess the growth stimulus of fluorescent Pseudomonas isolates at bracatinga seedlings. The seeds were inoculated with three bacterial isolates (CBSAL14, CBSAL18 and CBSAL05), genetically identified as Pseudomonas sp. They were previously grown in $50 \mathrm{~mL}$ of Luria Bertani medium for $48 \mathrm{~h}$ and then the seeds were submerged for 30 min in the suspensions. Subsequently, they were sown in tubes containing sterilized commercial substrate and kept in greenhouse for five months. From 61 days after sowing, seedling height and stem diameter were measured monthly. The CBSAL14 and CBSAL18 isolates promoted promoted increase in growth of seedlings height of inoculated individuals compared to control, suggesting their potential use as plant growth promoters.
\end{abstract}

\section{Influência de Pseudomonas fluorescentes no desenvolvimento de mudas de Mimosa scabrella}

\begin{abstract}
Resumo - A bracantiga (Mimosa scabrella Benth) é uma leguminosa nativa do sul do Brasil, com grande potencial para uso comercial. Pode ser usada para a recuperação de áreas degradadas, devido ao seu rápido crescimento, alta adaptabilidade e capacidade de formar nódulos. Uma alternativa para reduzir custos de fertilização na produção de mudas, é o uso de rizobactérias promotoras de crescimento de plantas. O grupo fluorescente de Pseudomonas é comum nas rizosferas de diversas espécies de plantas. Neste trabalho, o objetivo foi avaliar o estímulo de isolados de Pseudomonas fluorescentes nas plântulas de bracatinga. As sementes foram inoculadas com três isolados bacterianos (CBSAL14, CBSAL18 e CBSAL05), geneticamente identificados como Pseudomonas sp. Foram, previamente, cultivados em $50 \mathrm{~mL}$ de meio Luria Bertani por $48 \mathrm{~h}$, submergindo as sementes, na sequência, por 30 min nas suspensões. Posteriormente, foram semeadas em tubetes contendo substrato comercial esterilizado e mantidas em casa-de-vegetação por cinco meses. A partir dos 61 dias após a semeadura, a altura da muda e o diâmetro do coleto foram mensurados mensalmente. Os isolados CBSAL14 e CBSAL18 promoveram aumento do incremento em altura das plântulas de indivíduos inoculados em relação ao controle, sugerindo seu potencial de uso como promotores do crescimento das plantas.
\end{abstract}




\section{Introduction}

Mimosa scabrella Benth known as bracatinga is a native tree of southern Brazil, belonging to the Fabaceae family. It is a wood species, perennial, and has low demands on physical and chemical soil features (Steenbock et al., 2011; Menegatti et al., 2019). The growth starts fast, enabling the tree to reach 20 and $30 \mathrm{~cm}$ at $1.30 \mathrm{~m}$ above ground level (DBH) and an average height of $15 \mathrm{~m}$. However, when under adverse soil conditions and topography, its height can be jeopardize, reaching only approximately $3 \mathrm{~m}$ (Mazuchowski et al., 2014).

According to Guareschi et al. (2015), forestry of native tree species are not properly handled for commercial purposes. However, they are demanded for environmental reforestation projects and recovery of degraded areas or landscape. For these reasons, these authors mention that it is important to know and control their seeds and seedlings quality.

Mimosa scabrella is a perennial plant and a facilitating species. It contributes in recovering degraded areas, minimizing in a few months the effects of weathering, avoiding the leaching and erosion processes and contributing to the incorporation of high levels of nitrogen and phosphorus (Saturno \& Andrade, 2015; Silva et al., 2019).

In degraded areas projects, it is necessary a very high number of plants and it is important to reduce costs. In addition, chemical fertilizers can cause environmental impacts (Santos et al., 2018). Therefore, it is necessary to find alternatives that enable the seedlings production. The use of plant growth promoting microorganisms is a promising and low-impact option to reduce and to optimize chemical fertilizer use, ensuring high yield and lower cost-benefit ratio (Spolaor et al., 2016; Santos et al., 2018).

Several authors have described that plant growth promoting rhizobacteria (PGPR) represents a variety of soil bacteria that may associate to plants, stimulating their growth. They are biofertilization, bioremediation, biopesticides and phytostimulators (Pereira et al., 2008; Marques \& Uesugi, 2013; Graças et al., 2015; Souza et al., 2015; Cardoso \& Andreote, 2016; Santos et al., 2018; Qessaoui et al., 2019).

Among several genera described, Pseudomonas and Bacillus are the most studied (Das et al., 2013; Santos et al., 2018; Ferreira et al., 2019). The fluorescent group has the highest number of species within the genus Pseudomonas (Botelho \& Mendonça-Hagler, 2006; Marques \& Uesugi, 2013; Sonawane et al., 2014). The species stand out for their nutritional versatility and ability to grow at diverse environments and substrates. In addition, they have the ability to improve growth, plant health and biocontrol, due to their production of secondary metabolites (Méliani et al., 2017; Turatto et al., 2018).

Several parameters may be evaluated to demonstrate the influence on seedlings quality, estimating PGPR contribution to the early development of forest species. Among them, the most used are plant height and stem diameter. These parameters are easily measured and they can provide reliable data on seedlings strength and functionality (Nicoletti et al., 2015; Santos et al., 2018). The stem diameter is the most analyzed feature to indicate the seedlings survival capacity in the field (D'avila et al., 2011). However, they should not be considered individually when determining seedlings quality, due to their close relatedness. The evaluation of both parameters can help to determine higher quality seedlings.

In this work, the objective was to evaluate the influence of fluorescent Pseudomonas on the development of $M$. scabrella seedlings.

\section{Material and methods}

The present study was carried out at Federal University of Santa Catarina in Curitibanos, Santa Catarina State. We used four rhizobacteria isolates from garlic rhizosphere (Botelho et al., 2019), from the microorganisms collection of the laboratory of plant growth.

For isolates identification, DNA extraction, Polimarase Chain Reaction (PCR) amplification and PCR fragments sequencing were performed according to the following methods: isolates were grown in Luria Bertani medium (LB) for $24 \mathrm{~h}$ at $28^{\circ} \mathrm{C}$ under stirring at $120 \mathrm{rpm}$. Then, $2 \mathrm{~mL}$ of cell suspension were centrifuged $(12,000 \times$ g) and the total genomic DNA was extracted using a Wizard ${ }^{\circledR}$ Genomic DNA Purification Kit (Promega, USA), following the manufacturer's instructions. Amplification was performed at a volume of $50 \mu \mathrm{L}$, containing approximately $50 \mathrm{\eta g}$ template DNA, $1 \mathrm{x}$ buffer, $1.75 \mathrm{mM} \mathrm{MgCl}, 0.25 \mathrm{mM}$ each dNTP, $0.20 \mathrm{mM}$ both, 27F primer and 1492R primer (sequence of primer 
and reference) and Taq polymerase 1.5 U. 16S RNAr sequencing was carried out at Embrapa Agrobiologia (Botelho et al., 2019), using sense and antisense primers on the Applied Biosystems 3500 equipment. Contigs assembly was performed using the BioNumerics 7.0 program.

Mimosa scabrella seeds were collected from ten mother plants in the surrounding campus area in 2016. They were manually benefited by sifting, to discard immature, deteriorated or damaged seeds.

Before isolates inoculation, the seeds were immersed in water at $80^{\circ} \mathrm{C}$ for $24 \mathrm{~h}$ (Brasil, 2013). Then, they were disinfested by immersion in $95^{\circ}$ alcohol for $5 \mathrm{~min}$ and in sodium hypochlorite $3 \%$ for $2 \mathrm{~min}$. They were washed six times with sterilized distilled water and dried in laminar flow.

The four rhizobacteria isolates (treatments $-\mathrm{T}$ ) were CBSAL02 - T2, CBSAL14 - T3, CBSAL05 - T4 and CBSAL18 - T5. They were inoculated into flasks containing $50 \mathrm{~mL}$ of liquid LB medium, for $48 \mathrm{~h}$ at $27^{\circ} \mathrm{C}$, as well as the control, without inoculation (T1). Sixteen seeds in each bacterial suspension and the medium without inoculation (control) were dried for $30 \mathrm{~min}$ under laminar flow in sterile plates. Subsequently, tubes (volume $=290 \mathrm{~cm}^{3}$ ) containing previously sterilized commercial substrate of each treatment received three seeds. They were placed in greenhouse, at $\pm 25^{\circ} \mathrm{C}$ and 2 min irrigation every hour.

Seedlings thinning was carried out when they reached $5 \mathrm{~cm}$, leaving only one per tube. They stayed in the greenhouse for 5 months. The analyzed parameters were height $(\mathrm{H})$ and stem diameter $(\mathrm{CD})$. Height was measured by centimeter-graduated ruler and stem diameter by an electronic caliper. The first assessment was carried out at 61days after sowing and following monthly, along five months. The experimental design was completely randomized with 5 treatments and 19 replicates. The Analysis of variance (ANOVA) and Scott-Knott mean test were performed using the statistical package DEX/UFLA Sisvar 5.7 (Build 91).

\section{Results}

At King B medium, the isolates emitted fluorescence that are typical of the fluorescent group of Pseudomonas. According to $16 \mathrm{~S}$ RNAr sequencing, the four isolates tested belong to the genus Pseudomonas (Table 1).

Table 1. Isolates identification by $16 \mathrm{~S}$ RNAr gene sequencing for Pseudomonas sp. 99\% similarity and E value $=0.0$

\begin{tabular}{cc}
\hline Isolates & ID/NCBI \\
\hline CBSAL02 & KT321658.1 \\
CBSAL05 & LT629702.1 \\
CBSAL14 & LT629702.1 \\
CBSAL18 & KT321658.1 \\
\hline
\end{tabular}

The seedlings height and stem diameter for each treatment over time is presented in Figure 1. Seedlings showed bigger heights when inoculated with CBSAL14 and CBSAL18 isolates $(25.02 \mathrm{~cm}$ and $24.27 \mathrm{~cm}$, respectively). Other treatments presented average height of $20 \mathrm{~cm}$, at 150 days. CBSAL14 and CBSAL18 inoculated seedlings also showed higher increase in height $(0.19 \mathrm{~cm}$ and $0.18 \mathrm{~cm}$, respectively) over time, when compared to the control $(0.16 \mathrm{~cm})$ and the other treatments $(0.15 \mathrm{~cm})$.

It was possible to verify that the initial growth height of seedlings inoculated with CBSAL05 $(7.1 \mathrm{~cm})$, CBSAL14 $(7.12 \mathrm{~cm})$ and CBSAL18 $(6.95 \mathrm{~cm})$ isolates had better performance than the control $(5.97 \mathrm{~cm})$ and CBSAL02 isolate $(5.97 \mathrm{~cm})$.
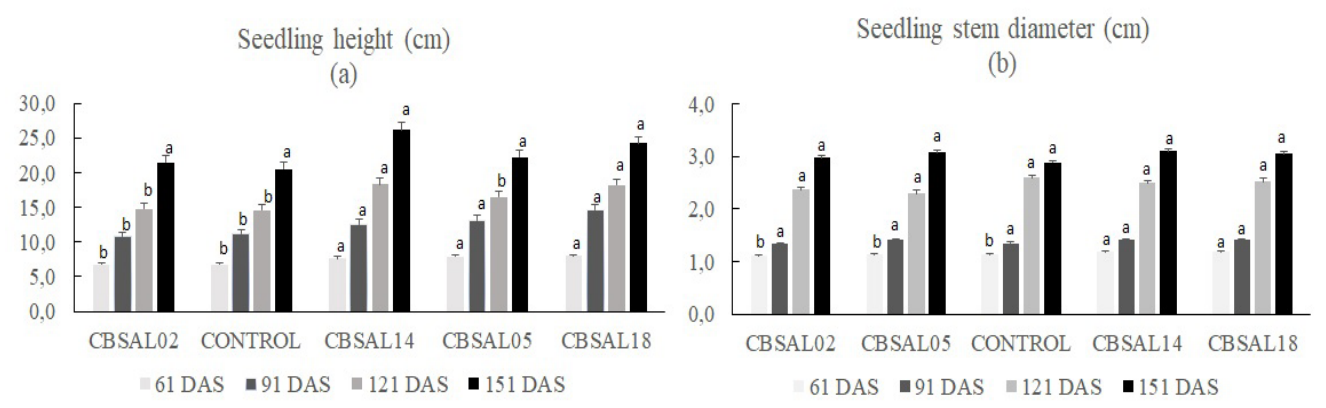

Figure 1. Height (a) and stem diameter (b) of Mimosa scabrella seedlings inoculated with fluorescent Pseudomonas sp. DAS - days after sowing. Treatments followed by the same letters did not differ statistically by Scott-Knott average test at 5\%. 
At 121 DAS, height increase was observed only at CBSAL14 and CBSAL18, although they showed no significant difference among treatments and control at 151 DAS. The CBSAL02 isolate stimulus did not differ statistically from the control over time (Figure 1).

The final stem diameter showed no difference among treatments. However, the increase in the diameters of plants inoculated with CBSAL14, CBSAL18 and CBSAL05 isolates was significant over time.

\section{Discussion}

Previous results indicated that the isolates used in this research promoted plant development. CBSAL02, CBSAL05, CBSAL14 and CBSAL18 stimulated the size of the fourth leaf of garlic, that is related to its bulbification and production (Botelho et al., 2019).

These isolates demonstrated ability to solubilize calcium phosphate and produce IAA (Indole Acetic Acid) in vitro (Botelho et al., 2019), suggesting their potential to plant growth induction. It is important to emphasize that fluorescent Pseudomonas are common in the rhizosphere of different plant species (Ferreira et al., 2009; Méliani et al., 2017; Lopes et al., 2018), indicating their ability to adapt and metabolize different plant exudates.

For seedling production, techniques that aim at shortterm production and high-quality plants to successfully establish themselves at the field are extremely important. They result in high percentage of survival and replanting reduction (Felker et al., 2015). It is common to perform the inoculation of beneficial microorganisms in plants in order to improve their development, as well as to increase tolerance to diseases and enable the establishment under stress conditions such as salinity and drought (Niu et al. 2018; Ferreira et al., 2019). Raasch et al. (2013) observed that microorganisms influenced Eucalyptus seedlings, decreasing, decreasing their period in the nursery and enhancing their establishment in the field.

It was possible to verify that the seedlings inoculated with CBSAL05, CBSAL14 and CBSAL18 isolates showed a better performance of initial height growth than the control and CBSAL02. These results are similar to those at Raasch et al. (2013), that observed increase in the height of inoculated Eucalyptus minicuttings. Brunetta et al. (2010), evaluating rhizobacterial isolates in Pinus taeda, observed that four isolates significantly induced growth of seedlings aerial part. This initial growth can be important for faster seedling's development, reducing their nursery time.

According to Raasch et al. (2013), height should not be the only parameter to represent the quality of seedlings, especially when there is no balance between the shoot and the root system.

This parameter is influenced by environmental conditions, population density and nutritional status. When evaluated in the field, the stem diameter is considered a reliable feature, since it is easy to be measured and has high correlation to the seedling survival, thus helping to determine the quality of seedlings (Nicoletti et al., 2015). Rudek et al. (2013) and Nicoletti et al. (2015) studying Eucalyptus sp., observed that the combination of leaf area and stem diameter was a reliable parameter when determining seedling quality.

According to Araujo et al. (2014), within the same species, the larger diameter provides higher plant survival, since it indicates its ability to produce more roots. The authors also mentioned that the stem diameter and height are essential for evaluating survival potential and post-planting seedlings of forest species growth.

In general, the isolates CBSAL14 and CBSAL18 promoted the highest increase in plant height and diameter over the 150 day, differing from the control and others isolates. The CBSAL02 isolate showed good results when tested with (Botelho et al., 2019), suggesting different forms of interaction, plant growth stimulation and adjustment in rhizobacteria communities among different plant species.

\section{Conclusions}

Two Pseudomonas isolates from fluorescent group (CBSAL14 and CBSAL18) increased the height of Mimosa scabrella seedlings, indicating their potential to be used as plant growth inducers in nurseries.

\section{Acknowledgments}

To Arielle Katyelle de Oliveira and Victoria Botelho Martins for statistical assistance.

\section{References}

Araujo, E. C. et al. Qualidade das mudas de espécies arbóreas de mangue cultivadas em viveiro e diferentes substratos. Acta Ambiental Catarinense, v. 11, p. 1-2, 2014. http://dx.doi. org/10.24021/raac.v11i1/2.1798. 
Botelho, G. R et al. Plant growth promoting bacteria from garlic sowed at Curitibanos micro-region - Santa Catarina - Brazil. Ciencia del Suelo, v. 37, n. 1, p. 51-65, 2019. Available from: http://www. suelos.org.ar/publicaciones/Volumen37n1/6-\%20467\%20WEB.pdf. Access on: 26 dez. 2019.

Botelho, G. R. \& Mendonça-Hagler, L. C. Fluorescent Pseudomonads associated with the rhizosphere of Crops - an overview. Brazilian Journal of Microbiology, v. 37, p. 401-416, 2006. http://dx.doi. org/10.1590/S1517-83822006000400001.

Brunetta, J. M. F. C. et al. Isolamento e seleção de rizobactérias promotoras do crescimento de Pinus taeda. Revista Árvore, v. 34, n. 3, p. 399-406, 2010. http://dx.doi.org/10.1590/S010067622010000300003 .

Brasil. Ministério da Agricultura, Pecuária e Abastecimento. Instruções para análise de sementes de espécies florestais. Brasília: MAPA, 2013. 98 p. Available from: https://www.gov.br/agricultura/ pt-br/assuntos/laboratorios/arquivos-publicacoes-laboratorio/ florestal_documento_pdf-ilovepdf-compressed.pdf. Access on: 23 nov. 2020 .

Cardoso, E. J. B. N. \& Andreote, F. D. (ed.). Microbiologia do solo. 2 ed. Piracicaba: ESALQ, 2016. 221 p.

Das, A. J. et al. plant growth promoting rhizobacteria (PGPR): an alternative of chemical fertilizer for sustainable, environment friendly agriculture. Research Journal of Agriculture and Forestry Sciences, v. 1, n. 4, p. 21-23, 2013.

D'Avila, F. S. et al. Efeito do potássio na fase de rustificação de mudas clonais de eucalipto. Revista Árvore, v. 35, n. 1, p. 13-19, 2011. http://dx.doi.org/10.1590/S0100-67622011000100002.

Felker, R. M. et al. Crescimento de mudas de Açoita-cavalo (Luehea divaricata Mart.) sob influência de diferentes substratos e recipientes, em viveiro. Enciclopédia Biosfera, v. 11, p. 22, 2015. http://dx.doi. org/10.18677/Enciclopedia_Biosfera_2015_120.

Ferreira, C. M. H. et al. Promising bacterial genera for agricultural practices: An insight on plant growth-promoting properties and microbial safety aspects. Science of the total environment, v. 682, p. 779-799, 2019. http://dx.doi.org/10.1016/j.scitotenv.2019.04.225.

Ferreira, E. P. B. et al. Diversidade de Pseudomonas fluorescentes em diferentes sistemas de manejo do solo e rotação de culturas. Revista Brasileira de Ciências Agrárias, v. 4, n. 2, p. 140-148, 2009. Available from: https://www.alice.cnptia.embrapa.br/alice/ bitstream/doc/256383/1/RBCAFerreira.pdf. Access on: 26 dez. 2019.

Graças, J. P. et al. Microrganismos estimulantes na agricultura. Piracicaba: ESALQ - Divisão de Biblioteca, 2015. 56 p.

Guareschi, D. G. et al. Envelhecimento acelerado de sementes e qualidade de plântulas de Bauhinia forficata Link em diferentes substratos e tamanho de tubetes. Revista Agro@mbiente Online, v. 9, n. 1, p. 65-71, 2015. https://doi.org/10.5327/Z19828470201500012175 .

Lopes, M. J. et al. Effect of Pseudomonas fluorescens and Burkholderia pyrrocinia on the growth improvement and physiological responses in Brachiaria brizantha. American Journal of Plant Sciences, v. 9, p. 250-265, 2018. https://doi.org/10.4236/ajps.2018.92021.
Marques, E. \& Uesugi, C. H. Avaliação de bactérias extremófilas facultativas na produção de fitomassa do híbrido urograndis de eucalipto, a partir de sementes. Revista Árvore, v. 37, n. 1, p. 4147, 2013.

Mazuchowski, J. Z. et al. Bracatinga, Mimosa scabrella Bentham: cultivo, manejo e usos da espécie. Florianópolis: Epagri, 2014. 365 p.

Meliani, A. Plant growth-promotion and IAA secretion with Pseudomonas fluorescens and Pseudomonas putida. Research \& Reviews: Journal of Botanical Sciences, v. 6, n. 2, p. 16-24, 2017.

Menegatti, R. D. Biometric and physiological quality of bracatinga seeds from different mother trees. Floresta e Ambiente, v. 26, n. 1, p. 1-10, 2019. http://dx.doi.org/10.1590/2179-8087.035916.

Nicoletti, M. F. et al. Modelagem de variáveis morfológicas em mudas de Eucalyptus dunnii. Floresta, v. 45, n. 4, p. 809-818, 2015. http://dx.doi.org/10.5380/rf.v45i4.37454.

Niu, X. et al. Drought-tolerant plant growth-promoting rhizobacteria associated with foxtail millet in a semi-arid agroecosystem and their potential in alleviating drought stress. Frontiers in Microbiology, v. 8, p. 1-11, 2018. https://doi.org/10.3389/fmicb.2017.02580.

Pereira, R. M. et al. Avaliações de populações de possíveis rizobactérias em solos sob espécies florestais. Revista Brasileira Ciência do Solo, v. 32, p. 1921-1927, 2008. https://doi.org/10.1590/ S0100-06832008000500013.

Qessaoui, R. et al. Applications of new rhizobacteria Pseudomonas isolates in agroecology via fundamental processes complementing plant growth. Scientific Reports Scientific Reports, v. 9, n. 12832, p. 1-10, 2019. https://doi.org/10.1038/s41598-019-49216-8.

Raasch, L. D. et al. Bacillus subtilis: Enraizamento e crescimento de miniestacas de eucalipto em Sinop, Norte de Mato Grosso, Brasil. Bioscience Journal, v. 29, n. 1, p. 1446-1457, 2013.

Rudek, A. et al. Avaliação da qualidade de mudas de eucalipto pela mensuração da área foliar com o uso de imagens digitais. Enciclopédia Biosfera, v. 9, n. 17, p. 3775, 2013.

Santos, R. F. dos et al. Inoculation of Pinus taeda seedlings with plant growth-promoting rhizobacteria. Floresta e Ambiente, v. 25, n. 1, p. 1-7, 2018. http://dx.doi.org/10.1590/2179-8087.005616.

Saturno, D. F. \& Andrade, D. S. Diversidade de rizóbios que nodulam bracatinga isolado de solos cultivados e de floresta. Uniciências, v. 19, n 1, p. 26-30, 2015.

Silva, E. P. da et al. Soil attributes in coal mining areas under recovery with bracatinga (Mimosa scabrella). Letters in applied microbiology, v. 68, n. 6, p. 497-504, 2019. http://dx.doi.org/10.1111/lam.13153.

Sonawane, R. B. et al. Isolation, characterization, functional potential and molecular diversity of Pseudomonas fluorescens isolated from the soils of Maharashtra. Research Journal of Biotechnology, v. 9, n. 11, p. 92-103, 2014.

Souza, R. de et al. Plant growth-promoting bacteria as inoculants in agricultural soils. Genetics and Molecular Biology, v. 38, n. 4, p. 401-419, 2015. http://dx.doi.org/10.1590/S1415-475738420150053.

Spolaor, L. T. et al. Bactérias promotoras de crescimento associadas à adubação nitrogenada de cobertura no desempenho agronômico de milho pipoca. Bragantia, v. 75, n. 1, p. 33-40, 2016. http://dx.doi. org/10.1590/1678-4499.330. 
Steenbock, W. et al. Mimosa scabrella: Bracatinga. In: Coradin, L. et al. (ed.). Espécies nativas da flora brasileira de valor econômico atual ou potencial: plantas para o futuro. Brasília: MMA, 2011. p. 478-493.
Turatto, M. F. et al. Control potential of Meloidogyne javanica and Ditylenchus spp. using fluorescent Pseudomonas and Bacillus spp. Brazilian Journal of Microbiology, v. 49, p. 54-58, 2018. https:// doi.org/10.1016/j.bjm.2017.03.015. 